\title{
Histological and proximate analysis of ash produced from sesame, palm fruit and Parkia on albino rats
}

\author{
Celestina Adebimpe Ojo 1, *, Makanju Dehinde Awogbenja 2, Eunice Adigizi 2 and Tomiwa Johnson Oyedokun \\ 1 \\ 1 Department of Human Nutrition and Dietetics, Faculty of Food Technology University of Agriculture Krakow, Poland. \\ 2 Departments of Nutrition and Dietetics, Faculty of Agriculture, Nasarawa State University Keffi, Shabu-Lafia.
}

International Journal of Biological and Pharmaceutical Sciences Archive, 2021, 02(02), 026-030

Publication history: Received on 01 September 2021; revised on 30 October 2021; accepted on 01 November 2021

Article DOI: https://doi.org/10.53771/ijbpsa.2021.2.2.0077

\begin{abstract}
The customary puerperal usage of Natron consumption has been identified as one of the risk factors in the cause of high blood pressure in human as well as kidney diseases and abortion in early pregnancies in female. This study was done to determine the effect of Natron and other Natron alternatives on the histology of kidney and liver in male Wistar Albino rats Twenty-five Wistar albino rats of the same sexes (male) weighing 100-140 kg body weights were used and were divided into five groups. Group 1, 2, 3 and 4 were fed with feed mixed with natron powder, feed mixed with wood ash, feed mixed with sesame ash, feed mixed with palm fruit bunch ash respectively, while group 6 served as a normal control (fed with plain feed). The animals were kept in plastic cages, allowed to acclimatize for two weeks before the commencement of the experiment. They were fed with pelletized growers' feed (Vital feed) and were allowed access to water. The rats were fed with $25 \mathrm{~kg}$ of feeds for 12 days to allow them stabilized and recover from stress. Then the rats were fed with the pelletized feed for four weeks to all the groups. The animals were anaesthetized with chloroform vapour after 4 weeks and blood samples were collected through cardiac puncture into labeled tubes for electrolyte analyses. The labeled centrifuge tubes were allowed to stand for 30 minutes to clot and centrifuged at $4000 \mathrm{~g}$ for $10 \mathrm{~mm}$ and the serum obtained was pipette into labeled tubes. The organs were subjected to histology. The liver tissues were embedded in paraffin wax, sectioned at $5 \mu \mathrm{m}$ and stained by hematoxylin and eosin. Proximate analysis showed that natron, palm bunch ash, sesame stem ash, and parkia wood ash had crude protein values of 0.03\%, 0.05\%, 0.07\%, a nd $0.09 \%$ respectively. Fat and fiber were not present in both Natron and its alternatives. The appreciable amount of ash content in the food additives indicated good mineral preservation capacity. Parkia wood ash may contain toxic chemical substances that may affect the kidney and liver.
\end{abstract}

Keywords: Natron; Kidney; Histology; Ash

\section{Introduction}

Recent scientific studies have revealed that there has been an increased use of geological mineral substances as food for both human and animal (1) One of these is Natron, also called Potash, which is produced globally in a large amount above 30 million tons per year, mainly for use in fertilizers. Several types of fertilizer-potash has the single largest global industrial use of potassium. Potassium was initially gotten by electrolysis of caustic potash (aka potassium hydroxide), in 1807 (2). Potash is a type of lake salt (sodium bicarbonate) dried and hydrated in nature. This type of lake salt usually form and shoot out from the soil during rainy season but tends to fall off, solidify and dry up during the dry season (3). The ancient way of producing potassium carbonate $\left(\mathrm{K}_{2} \mathrm{CO}_{3}\right)$ involved gathering or producing wood ash from ash burning, leaching the ashes and thereafter evaporating the solution collected in large iron pots, leaving the pot ash (4).

\footnotetext{
${ }^{*}$ Corresponding author: Celestina Adebimpe Ojo

Department of Human Nutrition and Dietetics, Faculty of Food Technology University of Agriculture Krakow, Poland.
} 
Natron is commonly used in Nigeria for cooking. It is used as a tenderizer in cooking beans, added in Ewedu and Okro soup (Nigerian soups) during preparations in order to increase the viscosity of the soups. It has also been employed as a flavouring agent, used as food preservative, prophylactic and also for improving protein digestibility of cowpea $(5,6)$. Studies in the past have reveal that the use of Natron may be detrimental to the health if used in excessive quantity in food or water $(7,8)$. due to presence of various salts mixture with other earth impurities, which may be toxic and hazardous to humans' health. Furthermore, it has been discovered that Natron is not suitable for human health due to its high quantity of sodium and potassium that are associated with some heart diseases, thus reducing its consumption is highly important because natron cannot be digested by the human body, thereby causing health problems such as hypertension when ingested (9) Although the effect of Natron on biochemical and physiological parameters have been investigated but there is little or no information regarding its dietary effects in human liver and kidney (10). Therefore, this study sought to determine the effect of Natron and other Natron alternatives on the histology of kidney and liver in male Wistar Albino rats.

\section{Material and methods}

\subsection{Chemicals reagents and Experimental Animals}

All the chemicals, instrument, apparatus and reagents used for this work were analytically graded and purchased from reputable chemical laboratories. Wistar albino rats of the same sexes (male) weighing 100 - $140 \mathrm{~kg}$ body weights were used for this study. The animals were purchased from Central Animal Laboratory, Physiology Department, University of Ibadan, Nigeria. The animals were kept in plastic cages with wire cover at animal house and divided into 5 groups and were allowed to acclimatize for two weeks before the commencement of the experiment. They were fed with pelletized growers' feed (Vital feed) and were allowed access to water. The rats were treated according to the rules and regulations of animal ethics.

\subsection{Collection and Preparation of the Feeds and Food Additives}

Sesame ash was gotten from harvested sesame stem within Lafia farm and burnt into ash after which the ash was filtered and dried, same goes for the palm fruit bunch ash. Wood ash was gotten by burning parkia wood into ash filtered and dried. Natron (edible potash) was bought at Ogunpa market Ibadan Oyo state. The rat's feeds were purchased at second gate Ojoor raod Ibadan Oyo state. The samples were visually observed to notice its physical properties. The food additives were then weighed on a balance and stored in a stoppage container at room temperature until used.

The feeds which was in powdery form was weighed into four $12 \mathrm{~kg}$ each and $500 \mathrm{~g}$ of each treatment was added into each $12 \mathrm{~kg}$ and then it was pelletized with a pelletizing machine at second gate Ojoor Ibadan Oyo state. The pelletized feeds were dried under sun for three days to increase its shelf life. The rats were fed with $25 \mathrm{~kg}$ of feeds for 12 days to allow them stabilized and recover from stress.

Then the rats were fed with the pelletized feed for four weeks in the following manner.

Treatment 1 had five rats in a cage fed with feed mixed with natron powder.

Treatment 2 had five rats in a cage fed with feed mixed with wood ash.

Treatment 3 had five rats in a cage fed with feed mixed with sesame ash.

Treatment 4 had five rats in a cage fed with feed mixed with palm fruit bunch ash

Treatment 5 had five rats in a cage fed with plain feed (control).

\subsection{Animal Studies (Bioassay)}

\subsubsection{Organs Collection}

The rats were sacrificed by cervical dislocation and were cut open to get access to the organs (kidney and liver). The organs were subjected to histology test at the Histology Laboratory School of Veterinary University of Ibadan. 


\subsubsection{Preparation and Staining of Tissues and Histological Examination}

As soon as the animals were sacrificed, they were quickly dissected, the liver removed, and the slices immediately fixed in a fixative (10\% buffered formalin), transferred into specimen bottles, and kept frozen for 48 hours before being used. The liver tissues were embedded in paraffin wax, sectioned at $5 \mu \mathrm{m}$ and stained by hematoxylin and eosin. The photomicrographs were observed using Nikkon research microscope (Novex, Holland). The micrograph pictures were taken with digital camera (DCM 510.5M Pixels, CMOS chip) connected to the microscope.

\subsection{Proximate Analysis}

The food additives used in feeding the rats was subjected to proximate analysis at Institute of Agricultural Research and Training (MOOR Plantation) Obafemi Awolowo University Ibadan.

\section{Results and discussion}

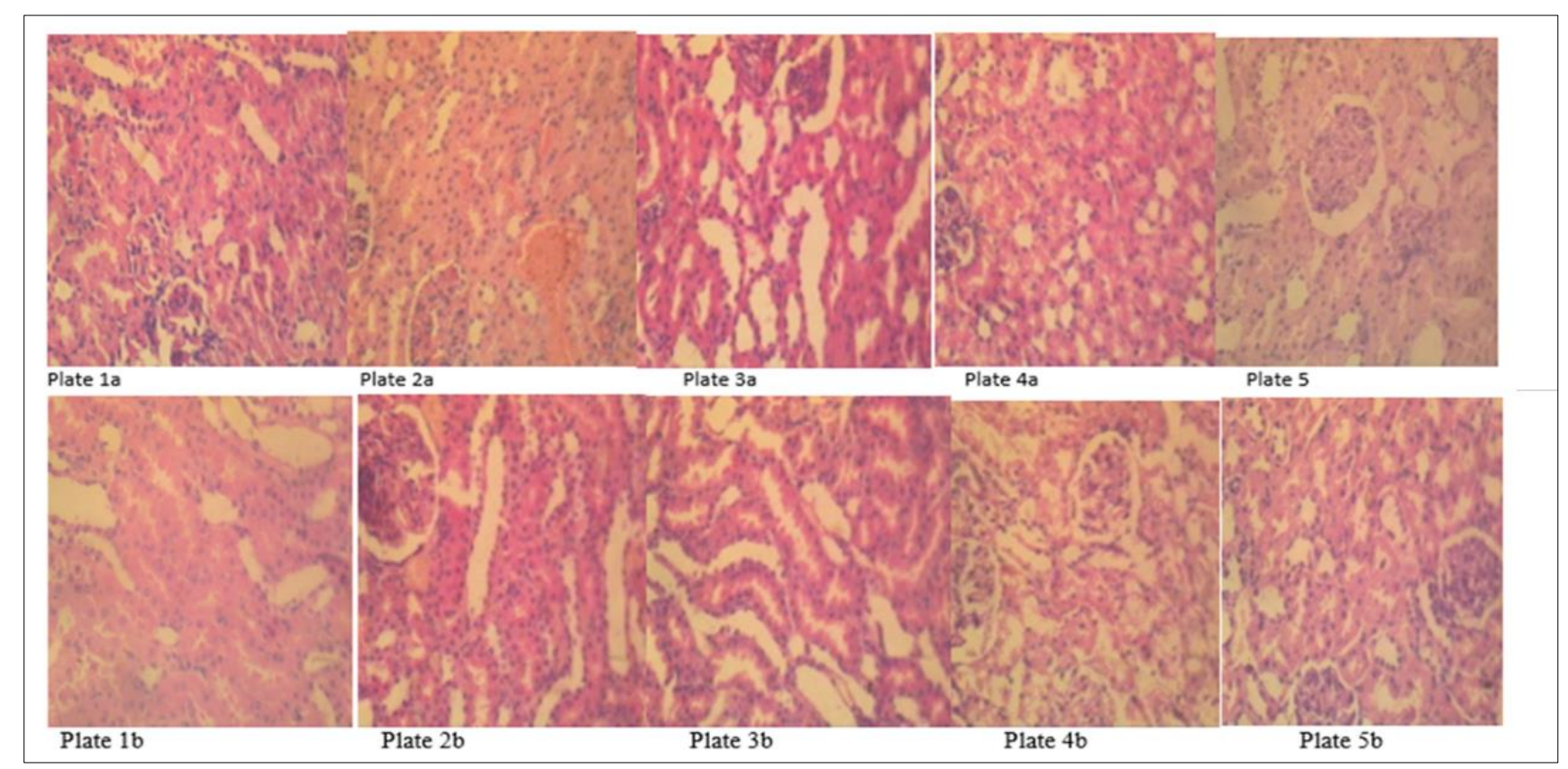

Plate 1a and 1b: kidney of albino rat fed with Natron; Plate 2a and 2b: kidney of albino rat fed with parkia wood ash; Plate 3a and 3b: kidney of albino rat fed with sesame ash; Plate 4a and 4b: kidney of albino rat fed with palm bunch ash; Plate $5 \mathrm{a}$ and $5 \mathrm{~b}$ : kidney of albino rat fed with plain feed

Figure 1 Photomicrograph of the Kidney

Table 1 shows the proximate analysis of Natron and Natron alternatives. Crude protein for natron, palm bunch ash, sesame stem ash, and parkia wood ash were $0.03 \%, 0.05 \%, 0.07 \%$, and $0.09 \%$ respectively. These findings are similar to the results obtained by Ijeh et al., (11) for palm bunch ash. Fat and fiber were not present in the food additives. The ash content in Natron and the alternatives was associated with the amount of mineral present (12). The appreciable ash content amount indicated good mineral preservation capacity. Effective mineral function is important for normal metabolism in the human system, minerals investigated were magnesium $19.53 \%$ in natron, 9.69\% in sesame stem ash, $9.72 \%$ in parkia ash and $9.85 \%$ in oil palm bunch), sodium (3.11\% in sesame stem ash, 3.18\% in both oil palm bunch ash and parkia tree ash, 3.89\% in natron) and phosphorus (12.59\% in oil palm bunch ash, $13.06 \%$ in sesame stem ash, $13.75 \%$ in parkia tree ash and $13.81 \%$ natron) were present in lower levels. Calcium content in the materials ranged from $20.67 \%$ in oil palm bunch ash, $21.92 \%$ in sesame stem ash, $23.89 \%$ in parkia tree ash, and natron has the highest with $26.75 \%$ and potassium content ranges from $4.79 \%$ in oil palm bunch ash, $4.95 \%$ in parkia tree ash, $5.21 \%$ in sesame stem ash and $7.86 \%$ in natron. Generally, calcium and potassium are required for cellular functions with recommended allowance for adolescents and adults up to $1300 \mathrm{mg}$ daily (calcium) and (phosphorus) (13). Calcium deficiencies result in the developments of type1 and type2 diabetes (14). However, in recent studies carried out, it has been shown that the accumulation of calcium oxalate monohydrate (COM) crystals in kidney tissue produces renal tubular necrosis which can result into kidney failure and that renal toxicity can be attributed to COM crystals accumulation in the kidney (15). 
Table 1 Proximate analysis of Natron and Natron alternatives

\begin{tabular}{|l|l|l|l|l|l|l|l|l|l|}
\hline $\begin{array}{l}\text { Sample } \\
\text { Description }\end{array}$ & $\begin{array}{l}\text { \% Crude } \\
\text { protein }\end{array}$ & $\begin{array}{l}\text { \% Fat ether } \\
\text { extract }\end{array}$ & $\begin{array}{l}\text { \% Total } \\
\text { fiber }\end{array}$ & $\begin{array}{l}\mathbf{\%} \\
\text { Ash }\end{array}$ & $\begin{array}{l}\text { \% } \\
\text { M }\end{array}$ & $\begin{array}{l}\mathbf{\%} \\
\text { Ca }\end{array}$ & $\begin{array}{l}\text { \% } \\
\text { P }\end{array}$ & $\begin{array}{l}\text { \% } \\
\text { Na }\end{array}$ & $\begin{array}{l}\text { K } \\
\text { K }\end{array}$ \\
\hline Natron & 0.03 & 0.00 & 0.00 & 88.67 & 9.53 & 26.75 & 13.81 & 3.89 & 7.86 \\
\hline Sesame stem ash & 0.09 & 0.00 & 0.00 & 89.67 & 9.69 & 21.92 & 13.06 & 3.11 & 5.21 \\
\hline $\begin{array}{l}\text { Oil palm bunch } \\
\text { ash }\end{array}$ & 0.05 & 0.00 & 0.00 & 88.94 & 9.85 & 20.67 & 12.59 & 3.18 & 4.79 \\
\hline Pakia tree ash & 0.07 & 0.00 & 0.00 & 89.83 & 9.72 & 23.89 & 13.75 & 3.18 & 4.95 \\
\hline
\end{tabular}

Figure 2 shows the results of the histology of the Liver. The micrograph of the liver of Albino rats fed with natron, parkia wood ash, sesame ash, palm bunch ash and control are presented in plate $6 a$ \& 6b, 7a \& 7b, 8a \& 8b, 9a \& 9b and 10a \& $10 \mathrm{~b}$ respectively. There was no effect of the administered substances on the liver of Albino rats as it was observed that the organs examined did not show any form of cell destruction or damage except for the rats fed with parkia wood ash that showed foci thinning hepatic cords with resultant to dilated sinusoids and aggregates of nucleated in the portal blood vessels. The result of this study is in consistent with the result obtained (16) who concluded that high level of electrolytes in the liver cells could lead to liver damage. Furthermore, this result also agrees with the results of (17) that intake of natron has no effect on the effective functioning capacity of rats' liver.

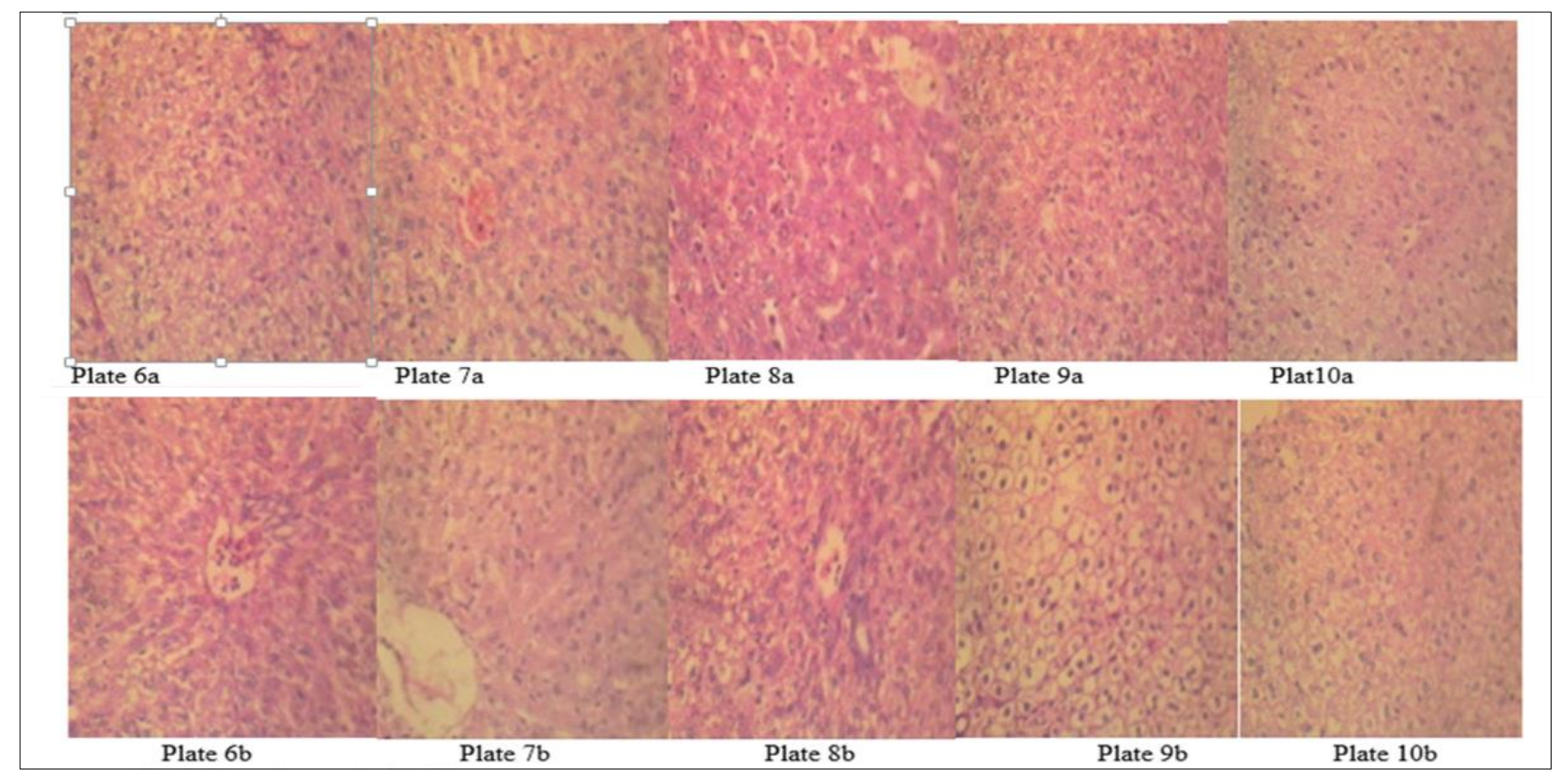

Plate $6 \mathrm{a}$ and $6 \mathrm{~b}$ : liver of albino rat fed with Natron; Plate $7 \mathrm{a}$ and $7 \mathrm{~b}$ : liver of albino rat fed with parkia wood ash; Plate 8a and 8b: liver of albino rat fed with sesame ash; Plate 9a and 9b: liver of albino rat fed with palm bunch ash; Plate 10a and 10b: liver of albino rat fed with plain feed

Figure 2 Photomicrograph of the Liver

\section{Conclusion}

This study revealed that the ash content had an appreciable amount as revealed by the mineral content, which indicates a good mineral preservation capacity parkia wood ash may contain toxic chemical substances that may affect the kidney and liver. The specific chemical constituents and mechanisms responsible for the effect of toxicity in wood ash are not very clear. However, it may be concluded that reactive metabolites of wood ash constitutes could have interaction with the kidney and liver tissues, causing damages to the glomerular functions and resulting in dilation sinusoids in the liver cells. Furthermore, the significant increase in the concentration of serum bicarbonate reported in this study might have resulted from the body of the rat having problem maintaining its acid base balance due to failure to remove carbon dioxide through the kidney. This might leads to kidney disease, shock, diabetic ketoacidosis or metabolic acidosis. 


\section{Compliance with ethical standards}

\section{Acknowledgement}

The authors wish to appreciate the support of staff of Histology Laboratory, School of Veterinary, University of Ibadan and Dr Kingsley Idahor of Animal Science Department, Nasarawa State University, Keffi for their contribution to see that this manuscript comes to a success.

\section{Statement of ethical approval}

The authors hereby declares that there's no conflict of interest and that we all agreed that the paper be published.

\section{References}

[1] Aribido SO Ogunmodede BK and Lakpini CAM Nutritional assessment of Gwanwarasa" Type of Natural Potash (Kanwa), Nigerian Journal of Chemical Research, 2001; 6,3:27-30. (PDF) Determination of Metals by Atomic Absorption Spectrometry in Unripe Plantain Peels Ash and Comparative Genotoxicity Studies with Kaun "Potash" Using Gel Electrophoresis and Diphenylamine Assay.

[2] Knight, D. Humphry Davy; Science and Power. Oxford: Blackwell. 1992; p 66

[3] Okpala, B. Benefits of Kaun Potash (Akanwu). Blog by Blessing Okpala. Global Food book Recipes for life. 2015 https://globalfoodbook.com/benefits-of-kaun-potash-akanwu/

[4] Dennis, K "Potash". 2005 Minerals Handbook. United States Geological Survey. 2006; p. 58.1

[5] Omueti O Morton I D; Emery W. Int. J. food Sci. and Nutrition, 1992; 43:147-153.

[6] Uzogara SG Morton ID Daniel J WJ Food Chemical, 1988; 30,2: 1-18.

[7] Davidson NM; Trevitt L; Parry EHO. Bulletin WHO 1974; 51:203

[8] Bello MO. Effect of repeated kanwa (Trona) consumption on some part of Gastrointestinal tract of rat. Ilorin Nigeria: Department of Biochemistry, University of Ilorin; 1988.

[9] George, R, Rogers, N, Kelley, S. Earliest magmatism in Ethiopia: evidence for two mantle plumes in one flood basalt province. Geology 1998; 26:923-926

[10] Oyeleke, AO Effect of consumption of kanwa in food and water on certain physiological states in rats. Nutr. 1988; 4:137-140

[11] Ijeh, I, Ejike, CECC, Nkwonta, OM and Njoku, BC. Effect of traditional processing techniques on the nutritional and phytochemical composition of African bread-fruit (Treculia africana) Seeds. J. Applied Sci. Environ. Manage. 2010; $14: 169-173$

[12] Egbuonu, ACC and Ezeanyika, LUS. L-arginine exposure improves renal function markers of metabolic syndrome in female rats. Am. J. Biochem. Mol. Biol. 2013; 3: 50-60.

[13] FAO/WHO,. Human vitamin and mineral requirements: Report of a joint FAO/WHO expert consultation Bangkok, Thailand. World Health Organization/Food and Agriculture Organization of the United Nations, Rome, Italy, 2001; pp: 161-162.

[14] Pittas, AG, Lau, J Hu, FB. and Dawson-Hughes, B. The role of vitamin D and calcium in type 2 diabetes. A systematic review and meta-analysis. J. Clin. Endocrinol Metab. 2007; 92: 2017-2029.

[15] Kenneth McMartin Are calcium oxalate crystals involved in the mechanism of acute renal failure in ethylene glycol poisoning?, Clinical Toxicology, 2009; 47 9: 859-869, DOI: 10.3109/15563650903344793

[16] Ewenighi CO, Dimkpa U, Ezeugwu U, Onyeanusi J, Onoh L, Adejumo B, Onoh G. Prevalence of hyperuricemia and its risk factors in healthy male adults from Abakaliki metropolis, Nigeria. J Mol Pathophysiol 2013; 4(3): $94-98$

[17] Bayomy, NA, Soliman, GM and Abdelaziz, EZ Effect of Potassium Bromate on the Liver of Adult Male Albino Rat and A Possible Protective Role of Vitamin C: Histological, Immunohistochemical, and Biochemical Study. Anat. Rec., 2016; 299: 1256-1269. https://doi.org/10.1002/ar.23386 